\title{
Factors Affecting Leveraging for Quoted Real Estate Development Companies in China
}

\author{
Lunani Abiud Simiyu ${ }^{1} \&$ Xuexi Huo ${ }^{1}$ \\ ${ }^{1}$ College of Economics and Management, Northwest A \& F University, Yangling, Xian, China \\ Correspondence: Xuexi Huo, College of Economics and Management, Northern Northwest A \& F University, \\ Yangling, Xian, China. Tel: 86-152-0922-5551. E-mail: xuexihuo@nwsuaf.edu.cn
}

Received: December 5, 2012

Accepted: May 28, $2013 \quad$ Online Published: June 20, 2013

doi:10.5539/ijef.v5n7p85

URL: http://dx.doi.org/10.5539/ijef.v5n7p85

\begin{abstract}
Real estate companies in China need to undertake capital restructuring by deepening and broadening additional sources of funding such as real estate investment trusts, venture capital, mezzanine financing and commercial mortgage backed securities. This study is aimed at analyzing the factors that influence leveraging among quoted real estate development companies in China. A sample of 90 real estate companies quoted on Shanghai Stock Exchange (SSE) and Shenzhen Stock Exchange(SZSE) for the period covering 2005 to 2011 was selected however, due to information inadequacy, only 68 samples were analyzed using fixed effects regression. The results exhibited the following; management experience, company size, "guanxi" common in china meaning (personal/business relationship), company growth, company profitability, asset tangibility were positive and significant to leverage, whereas; interest amount was negative and significant, business risk and company age were negative and insignificant to the company leverage. In overall, the outcome of the research is in line with predictions from various documented theories and previous works.
\end{abstract}

Keywords: real estate companies, leverage, capital, financing

\section{Introduction}

Real estate investment is a capital intensive venture so this has an implication that firms investing into this sector need to have a strong capital structure to sustain their development plans. The choices of capital structure by real estate companies generates peculiar interest because these firms can opt for different forms of corporate organization, each having significant implications for capital structure choices The existence of a huge gap between financial needs and availability of financing platform is a major hurdle along the growth path of real estate. Financing is incapacitated by very limited options to source for funds. McKinnon-Shaw (1973) argued that real rate of growth of an economy is slowed down by financial repression. Financial repression refers to government fixing interest rates and its adverse consequences on the financial sector and economy. McKinnon-Shaw paradigm, exhibit that with expansion of credit, abolishment or reduction in statutory reserve requirement and high interest rates, financial deepening is bound to occur. Hence, mobilizing cheap long term savings is very critical for this venture to match the long term span that characterizes real asset investment. The typical characters of real estate investments are long loan tenures and high degrees of leverage. In a perfect capital markets i.e. no information asymmetries, apart from consideration for taxation leverage has no impact on the investment decision.

China is the world largest developing economy with substantial financial and structural constraints in the financial system and institutional inertia (Chen, 2004). This scenario necessitates the need for massive financial reforms to create a smooth functioning of the countries' financial system. Roubini, N, Sala-i-Martin (1992), pointed out linking evidence emanating from a cross-country framework, providing additional evidence on how fast pace of economic growth is boosted by improved functioning of financial systems. A number of scholars have developed massive interest to explore the determinants of diverse capital structures in Chinese companies. According to Schwartz \& Aronson (1967), they were categorical that amongst industries, there exist different capital structures with different features. Quiet a number of empirical studies carried out have proved that there exist a strong industry effect that influence the kind of leverage structure of individual firms. Focusing on a particular type of industry, we can be able to yield this effect. For instance, real estate industry has peculiar 
characteristics such as regular income and leases, that positions this sector at advantageous position is renowned as a source of collateral for large sums of debt acquired. Such collateral are considered only, after valuation of existing real estate stocks and projected future developments.

In general practice, firms acquire funds from the financial market to finance their investments or expansion of their investments region wise or otherwise. They source for the funds in two ways; first, by floating company shares or stocks; secondly, through floating debt instrument such as debts. In tandem with this, capital structure implies the means by which companies finances their investments using a mix of debt and equity. Despite equity and debt being differing immensely by virtue of their nature, they complement each other as sources of finance for company investment projects. Subsequently, striking a best mix for both elements is key to achieve desired objectives of the leverage model. In circumstances where the firm does not balance debt and equity well, i.e. high proportion of debt, the firm may be constrained by debt servicing hence be exposed to risks such as changes in interest rates and business downturns. On the other hand, high equity proportions has the following implications; the company ownership structure is diluted in terms of vested interest by the stakeholders, company exposure to external control such as restrictive demands by debenture holders. This sends a signal that the firm is underutilizing its cash to obtain the assets of the company. Such phenomena will be discouraging both to existing and potential shareholders because the implication is; a proportionate size of earnings will be paid to equity providers as opposed to existing and potential shareholders.

The two most important dimensions that real estate companies must put into consideration while making capital structure decisions are leverage and maturity. In accordance with De Angelo et al, (2011), Leary and Roberts, (2010), Fama and French, (2002), they find it challenging to highlight whether companies attain an optimal debt structure and, if that is the case, which mechanism do they use to select this target of leverage ratio as per corporate finance literature. Subsequently, the remaining portion of this research will take the following format; section two, literature review, highlighting the developing and developed countries' companies financing decisions and the factors determining capital structures of companies. Hypothesis and variable definitions are spelled out in section three, while section four highlights sources of data and methodology applied in analyzing and testing data for the real estate leveraging in Chinese real estate companies. Section five highlights empirical results and data analysis. Last, but not least discussion and conclusions are highlighted in section six.

\section{Literature Review}

Different authors have documented varying views about capital structures for companies. For instance, Myers (1984) focuses on company debts basing on two aspects on corporate debt; that business trade-off by considering their tax obligation and how much they can save from what they owe against deadweight presented by cost of bankruptcy. Second attribute of adverse selection guides business on what mode of financing to undertake; this is because, different financing mode have different levels of adverse selection. Accordingly, the pecking order theory state that businesses will decide to finance their operation by outsourcing for equity only, in distressed circumstances, otherwise basing on adverse selection, they will plough back their profits, and in extreme circumstances use debt. The findings further state that; businesses will opt for their own finance before focusing on outside financing. In the event where outside finances are of necessity, businesses will first opt for debt then equity, this is informed by limited cost of information for floating debt. It is in remote circumstances that equity can be floated.

Shyam-Sunder and Myers (1999) fine tuned the findings into testable and verifiable concept highlighting that, when restructuring corporate debt proportion, financing sources should be balanced i.e. change in corporate debt should move in tandem with finance deficit of the firm. If a firm subscribes to the pecking order school of thought which hold that when net debts floated are regressed, a slope coefficient of one is observable. When it comes to deciding on sourcing external financing by firms, there are a number of characteristics that meets the threshold of pecking order theory to approve this financing. Myers (2001) asserts that major financing proportion are debts from external sources; the external funds account for a minor proportion of capital modeling, also notable is that equity accounts for little proportion of financing. The pecking order theory by Myers (1984) and Myers and Majluf (1984) was documented as follows; in the case of three financing modes that is debt, equity and retained earnings, retained earnings are not known to be affected by adverse selection, on the on the hand intense adverse selection highly characterizes equity, while this a attribute is very minimal on debt.

Equity posses much more riskier attribute than debt from observation of potential investor however, equity carries large premiums though both of sources of financing have adverse selection premium component, in finance literature and common practice, any potential investor would demand higher reward on equity than debt. 
From a company insider, profit plough back is viable source of financing, while debt option is better than equity because equity holders tend to benefit more through direct control of company operations and higher rewards. If financial obligations admit, businesses will plough back all profits to finance their projects. In case of a short fall of retained earnings, then debt financing should be the last option. The pecking order theory (POT) was originally suggested by Donaldson (1961) and put forth by Myers (1984) and Myers and Majluf (1984). The theory has been tested by Hughes $(1994,2003)$ and Myers and Sussman $(1999,2003)$. The theory studied the hierarchy of adopting alternative financial sources out of those that are available, under imperfectly informed markets. The theory suggests that firms have a ranking of preferences of financial sources. The trade-off theory of capital structure was formulated around the concept of target capital structure that balances between the benefit of debt-tax shields and cost (excess risk taking by shareholders) of debt financing.

Pecking order theory is categorical in the following ways; for a firm to obtain better operational performance, effective financial management and the caliber of attributes that affect their capital structures are critical. One of the major benefits of debt use is tax deductibility after interest has been factored and the only costs incurred are; bankruptcy costs as cited by (Kim, 1978) and agency costs as cited by (Jesen and Meckling, 1976; Myers, 1977). However, more recent studies have shown a focus shift towards pecking order theory as opposed to trade off theory as postulated by (Quan, 2002; Mazur, 2007).The pecking order theory assumption is that no target capital structure is required. Funding needs by firms are chosen as follows in that descending order: First internal finance, second debt, finally equity. Myers and Majluf (1984) posited that between managers (insiders) and investors (outsiders) there exist information asymmetry that keeps them at loggerheads in decision making.

They mention that by the virtue of position as managers, and engaged in operation, they are privy to insider information than investors, and this may influence their actions to be biased towards existing shareholders. The pecking order theory suggests that businesses prefer a particular order of funding used to finance their business operations (Myers and Majluf, 1984). Firms will prefer retained earnings to debt, short-term debt over long-term debt and debt over equity due to information asymmetries that exist between the firm and potential investors. Myers and Majluf (1984) argued that if firms only use its retained earnings to support the investment opportunities without floating any new security, then information asymmetric can be resolved. This implies that issuance of equity becomes more costly as the asymmetric information between insiders and outsiders increase. To counter selling under-priced securities; the firms that have large information asymmetry should float debt.

The capital restructuring such offering as new shares leads to dilution and a firm's stock price decline. The identified potential determinant of capital structure is the corporate performance. In accordance with the pecking order theory, the presence of asymmetric information, a firm will prefer internal finance, at later stage would issue debt once internal finance becomes limited. The worst case scenario would be issuance of new equity. Myers (1984) found out that between profitability and debt there exist a negative relation. Businesses that are more profitable are likely to have higher retained earnings as compared to low profitability businesses. High performing firms depend less on external finance. Chen (2004) employing a panel data of 77 Chinese quoted companies spanning the period between 1994 to 2000 in order to explore the determinants of capital structure in China. This was executed by scheming peculiar features of the China's firms going corporate and the embedded institutional environment which affect the firms'leverage decision. The findings showed that neither the trade-off school of thought nor the Pecking order hypothesis school of thought derived from the developing countries provides sufficient evidence for the capital options of the Chinese companies.

\subsection{Factors Determining Capital Structure}

The following factors are inherent in the determination of capital structure of companies; they include; management experience, company size, "guanxi"(personal /business relationship), Interest amount, company growth, company Profitability, asset tangibility, business risk and company age. They shall be discussed as follows;

Management experience: For its capital to be well structured and effectively utilized, a business firm must be able to devise various ways of selecting the best components of its capital which would be used in the company's operation to raise its productivity and or achieve performance. This process should be based on the criteria well drawn up by the finance manager after making a careful financial planning and control for the company (Uremadu, 2004).

Management Training: Well trained managers are an essential human resource asset to bring to the company competitive skills. A firm will have competitive edge over its peers because, managers with adequate skills can be able to turn around a company by driving up its growth through efficient and effective allocation of financial 
resources.

Company size: This determines financial leverage for virtually all sectors. All theories explaining capital structures have dwelled much on the existing connection between financial leverage and company size (Schoubben and van Hulle, 2004, p. 595). Corporate size is calculated by transforming total assets to natural logarithm. Measuring size of company as log of sales or use of absolute value of assets was supported by Huang and Song (2002). The reason for use of absolute value is of total sales or natural log of sales as a preffered computation of firm size is because the two are highly correlated with a coefficient of 0.79 . However, Pandey (2004), whose findings are among most recent applies natural log of total assets to compute firm size. Low risk brought about by the finance distress are demystified by the fact large firm have developed portfolio, great monitoring and transparency. (Ang et al. 1982; Myers 1984; Myers \& Majluf 1984) and Bevan and Danbolt, (1999) Large companies are advantaged in comparison with small venture become their credit rating structure are favored by the virtual of size.

Guanxi: According to Braendle et al., 2005; Wang, 2007; Liu et al., 2008 , "Guanxi” (business/personal relationship) in business necessitate easy flow of information and financial resources, this help to mitigate the problem of costs of transactions, efficiency improvement and resource allocation( Siu and Bao, 2008).

Interest amount(cost of capital):In the credit market, interest is the obligation of the borrower as an opportunity cost to "buyout" the creditor to postpone his current usage of funds and future investment possibilities (Nwachukwu, 1994) additionally, Nwaru, (2004) further stated that interest is used to cater for administration cost and possibly monitoring the loan to maturity. Therefore, in a nut shell, interest is the cost of money lent.

Company growth: Computed as the change in total assets between two consecutive years divided by previous year total assets. Thus, firms with high intangible growth opportunities will use more of equity rather than debt in their capital structure. Its hypothesized it will be negatively related to leverage.

Company Profitability: Brealey et al. 2008 in his works states that, the commonly applied determinant of company profits is return on assets (ROA).Profitability determines income shield and velocity of cash flow. Highly profitable firms have high income shield with high velocity of cash flow. As postulated by pecking order theory firms with higher profits (high internally generated funds) prefer to borrow less because it is easier and more cost effective to finance from internal fund sources. So, as per this theory, there will be an expected negative relation between profitability and leverage. On the contrary, trade-off theory suggests that this relationship would be positive. Since profitable firms are less likely to go bankrupt, and hence can avail more debt at cheaper rates of interest.

Asset tangibility: According to the findings of Gaud et al. 2005; Morri \& Beretta 2008, high level of leverage is normally associated with companies sizeable scale of tangible assets. Jensen \& Meckling 1976 argues from agent-theory perspective as follows; to counter agency relationship that is problems between equity owner and lenders, lenders would demand for security with tangibility characteristics. Wessels 1988; Westgaard et al. 2008) posit a significantly positive relation between debt and tangibility, with similar finding from Bradley et al. (1984), that the gearing and asset tangibility are positively related on the contrary, tangibility and gearing have a negative relationship as per Feng (2007) and Grossman and Hart (1982) finding. It is computed as a ratio of net of company fixed assets divided by company total assets. Since tangible assets are used as collateral, firms with large amount of fixed assets can borrow on favorable terms by providing the security of these assets to the lenders. Therefore, a high ratio of fixed assets-vs.-total assets should have a positive impact on firm leverage.

Business risk: defined as a short fall of earning from what was expected. Our hypothesis is that there exists a negative relation between business risk and leverage. Findings by DeAngelo and Masulis (1980) are to be relied on, there exists a positive dependence between retained earnings, equity demand.

Company age: According to Abor, (2008), reputation of the firm over time is defined by age. When company life cycle lengthens in operations the company positions as a going concern hence boost its probability to obtain more debt. The older the firm, the more the debt it can obtain, which support a positive leverage. Rajan and Zingales (1995) revisits age and concluded that quality firm exhibit high debt ratio than young firms. 


\section{Hypothesis and Variable Definations}

Table 1. Tabular presentation

\begin{tabular}{|c|c|c|c|c|}
\hline Variables & Variable Type & Computation & Theoretical Prediction & Expected Sign \\
\hline Leverage & Dependent & Total liabilities/ Total assets & N/A & \\
\hline Management experience & Independent & Number of yrs worked & N/A & Positive(+) \\
\hline Management training & Independent & Number of years trained & N/A & Positive(+) \\
\hline company size & Independent & Ln of assets & $\begin{array}{l}\text { Pecking order(-ve) } \\
\text { trade off(+ve) }\end{array}$ & Positive $(+)$ \\
\hline $\begin{array}{l}\text { "Guanxi”/business } \\
\text { relationship }\end{array}$ & Independent & Business relationship duration & N/A & Positive(+) \\
\hline Interest Financial cost & Independent & Ln of Interest paid & N/A & Negative(-) \\
\hline Company growth & Independent & Income changes & $\begin{array}{l}\text { pecking order }(+\mathrm{ve}) \\
\text { trade off }(-\mathrm{ve})\end{array}$ & Negative(-) \\
\hline Profitability & Independent & Net income/ Total assets & $\begin{array}{l}\text { pecking order(-ve) } \\
\text { trade off }(+v e)\end{array}$ & Negative(-) \\
\hline Asset tangibility & Independent & Fixed assets/total assets & $\begin{array}{l}\text { pecking order }(+v e) \\
\text { trade off }(+v e)\end{array}$ & Positive(+) \\
\hline Business risk & Independent & $\begin{array}{l}\text { Earnings variability year on } \\
\text { year }\end{array}$ & pecking order (-ve) & negative(-) \\
\hline Company age & Independent & Number of years of operation & $\begin{array}{l}\text { trade off }(-\mathrm{ve}) \\
\text { pecking order(-ve) } \\
\text { trade off }(+\mathrm{ve})\end{array}$ & Positive $(+)$ \\
\hline
\end{tabular}

\section{Data Sources}

The examination of factors affecting leverage is extracted from Trading Profit and loss accounts and balance sheets of real estate companies quoted on the Shanghai Stock Exchange and Shenzhen Stock Exchange. China Stock Market and Accounting Research Database (CSMAR) is charged with the responsibility of maintaining and managing this data.

\subsection{Methodology}

Stratified random sampling and simple random sampling methods were used in this study. The reason for employing the afore mentioned methods is to ensure adequate or proportional representation of the different financial structures of companies that make up the population.

\subsection{Model Specification}

Fixed effects regression model has been used to analyze capital leveraging pattern in real estate studies:

$$
\begin{gathered}
C A P L E V_{s s}=\beta_{0}+\beta_{1} M G T X P+\beta_{2} M G T T R+\beta_{3} C O S I Z+\beta_{4} G N X+\beta_{5} I N T R+\beta_{6} C O G R O+\beta_{7} P R O F+ \\
\beta_{8} A S S T A N+\beta_{9} B U Z R I S K+\beta_{10} C O A G E+\dot{\varepsilon}
\end{gathered}
$$

CAPLEV $_{\mathrm{ss}}$ - Capital Leverage supply; MGTXP-Management Experience; MGTTR- Management Training; COSIZE-Company size; GNXI-Guanxi; INTR-Interest; COGRO- Company Growth; PROF- Profitability; ASSTAN-Asset Tangibility; BUZRISK-Business Risk; COAGE- Company Age; ć-error term. 


\section{Empirical Results and Analysis}

Table 2. Estimated capital leverage supply function

\begin{tabular}{lll}
\hline Explanatory variables & coefficients and std errors & t-statistics \\
\hline Constant & $-5.782 \mathrm{E}+46(6004033)$ & -9.6302 \\
Management Experience & $16.9731^{* *}(6.4536)$ & 2.630 \\
Managers training level & $14.1938^{* *}(3.1113)$ & 4.562 \\
Company size & $2178620.12^{* *}(256257)$ & 8.5017 \\
"Guanxi" business r/ship & $4703.04 * * *(882.72)$ & 5.3279 \\
Interest & $-316.82 * *(10.061)$ & 31.4902 \\
Company growth & $104238.61(23220)$ & 4.4892 \\
Profitability & $394301.00^{* * *}(64215)$ & 6.1403 \\
Asset Tangibility & $75812.09 * *(5312.69)$ & 14.270 \\
Business risk & $-39014.39(5709.7)$ & 6.833 \\
Company age & $-95520.12(39880)$ & -2.3952 \\
Std. error of estimate & 3607.51 & \\
F & $7.36 * * *$ & \\
$\mathrm{R}^{2}$ & 0.463 & \\
\hline
\end{tabular}

Notes: a) Dependent variable here is Capital leverage Real estate Funds supply; ***P $=0.01, * * \mathrm{P}=0.05, * \mathrm{P}=0.1$. b) t-statistics, coefficients and standard errors were generated by SPSS software.

The above empirical results show that management experience and management training were both statistically significant at the 5\% level and exhibited our a priori expectation of positive sign with company leverage position. Managers are more amenable to risk taking than non-educated and in experienced ones because they are better equipped to access, evaluate and understand improved resource allocation techniques. Company size being positive and significant at $5 \%$ level confirms our a priori expectation that company age is positively related to debt. "Guanxi" (business/personal relationship) was positive and statistically significant at 5\% level confirming our apriori expectation that "guanxi" will influence company leveraging position. According to Braendle et al., 2005; Wang, 2007; Liu et al., 2008, "Guanxi" (business/personal relationship in business necessitate easy flow of information and financial resources, this help to mitigate the problem of costs of transactions, efficiency improvement and resource allocation (Siu and Bao, 2008). The amount interest paid on funds borrowed was significant at the 5\% level and had a negative sign. This is in line with a priori expectations and with the results from Desai \& Mellor (1993), Eboh \& Akpomedaye (1995), Nwaru (2004) and Essein (2009). Interest is the unit cost for taking credit. Ceteris paribus, as the cost increases, leveraging position changes, the reverse is true. In the credit market, interest is the obligation of the borrower as an opportunity cost to "buyout" the creditor to postpone his current usage of funds and future investment possibilities (Nwachukwu, 1994); additionally, to cater for administration cost and possibly monitoring the loan to maturity (Nwaru, 2004). Therefore, interest is the cost of money lent.

Company growth was positive; which was opposite to our a priori expectation in the hypothesis but it was statistically insignificant contrary to explanation that faster growing firms normally have a higher probability to undertake asset wealth transfer and substitution to share holders at the expense of bondholders. This additional agency costs of debt leads to a negative relationship between leverage and growth.Higgins (1977) posit that an indifference exits between long term debt and company growth. Since different signs are exhibited depending on whether the debt was long term or short term. A negative relation exists between growth and equity; while between growth and short term debt, there exists insignificance and between growth and long term debt there exists positive relationship.

Company profitability was statistically significant and positive at $1 \%$ as postulated by trade-off theory which suggests that this relationship would be positive. Since profitable firms are less likely to go bankrupt, and hence can avail more debt at cheaper rates of interest implying it has effect on company leverage.

Asset tangibility was positive as per our a priori expectation. It is statistically significant at the $5 \%$ level and this was also revisited by Westgaard et al. 2008) who concluded that there is a significantly positive relationship between debt and tangibility with similar finding by Bradley et al. (1984) found out that is a positive relationship between gearing and tangibility. If the findings by DeAngelo and Masulis (1980) are to be relied on, there exists a positive dependence between retained earnings and equity demand. However, our finding is that business risk is negative and insignificant. 
Company age was negative and insignificant which imply that company leveraging is not influenced by the duration of company existence. The F-value of 7.36 surpasses its significance at 5\% level. This confirms that there is a significant linear relationship between capital leverage and the associated variables. $\mathrm{R}^{2}$ is 0.463 , which indicates that about $46 \%$ of the total variations in the leveraging can be explained by the independent variables while $54 \%$ cannot be explained. The result suggest that company size and profitability greatly influence the behavior of fund supply (leverage) for real estate developers. Thus a unit rise in company size will lead to about 2178620.12 units rise in leverage, on the other hand a unit rise in profitability will lead to 394301units rise in funds needed (leverage).

\section{Discussion and Conclusions}

The study aimed at examining the factors that affect leverage for quoted real estate companies in China. Data was gathered from a stratified sample of 90 real estate developers however due to inadequacy of data, 68 companies capital components were analyzed. The analyses of data fixed regression model to evaluate the leveraging of quoted real estate companies, posit that interest amount significantly influenced leveraging at $5 \%$ and signed according to hypothesis. Other significant factors affecting leverage include; managers experience, managers training/ education, company size, guanxi (cultivated personal and business relationships), company profitability and asset tangibility. Business risk and company age had no significant impact on leverage supply more so, they were inappropriately signed. It could be concluded from this study that the leverage pattern of any company is very crucial in financing its development and growth study. This calls for prudent measures to facilitate optimal capital restructuring for the Quoted real estate companies.

Having analyzed the factors affecting leveraging in Chinese quoted real estate companies, we recommend the following:

The Chinese monetary authorities should continue with financial reforms in line with the Chinese principle of moderately developing nation with Chinese characteristics to enable most companies exploit the benefits of the financial system. Other sources of financing modes such as mezzanine financing, venture capital, commercial backed securities should be fast tracked from initiation, development to maturity to act as alternative sources of external financing. It is also necessary to improve the real estate financing regulations from in actual operation, strengthen the policy orientation of real estate development fund system and have a series of measures to establish a diversified real estate financing mechanism to promote real estate mortgage securitization.

Real estate companies need to develop their own tailored capital structures, why this is necessary is because there seems to be a general pattern across the industry which signals that most of the real estate companies capital structure are of similar nature.

The company size, company growth and profitability are key determinant factors in leveraging hence the company management team should adopt strategies that will drive growth of asset values and income levels of the companies.

\section{References}

Ang, J. S., Chua, J. H., \& McConnell. (1982). The Administrative Cost of Corporate Bankruptcy: A Note. Journal of Finance, 37(1), 219-226. http://dx.doi.org/10.1111/j.1540-6261.1982.tb01104.x

Bevan, A. A., \& Danbolt, J. (1999). Capital Structure in the United Kingdom 1991-1997 - A Dynamic, Cross-Sectional Approach. Paper Presented at the ACE Project Workshop Financial Flows and Debt Structures in Transition and Market Economies, Bulgaria, Hungary and the United Kingdom, Budapest, 15th May.

Bradley, M., Jarrel, G., \& Kim, E. H. (1984). On the Existence of an Optimal Capital Structure: Theory and Evidence. Journal of Finance, 39, 857-878. http://dx.doi.org/10.1111/j.1540-6261.1984.tb03680.x

Braendle, U. C., Gasser, T., \& Noll, J. (2005). Corporate governance in China - Is economic growth potential gindered by Guanxi. Bus. Soc. Rev., 110(4), 389-405. http://dx.doi.org/10.1111/j.0045-3609.2005.00022.x

Brealey, R. A., Myers, S. C., \& Allen, F. (2008). Principles of Corporate Finance (9th ed.). New York: McGraw-Hill.

Chen, J. J. (2004). Determinants of capital structure of Chinese-listed companies. Journal of Business Research, 57, 1341-1351. http://dx.doi.org/10.1016/S0148-2963(03)00070-5

DeAngelo, H., \& Masulis, R. W. (1980). Optimal Capital Structure under Corporate and Personal Taxation. Journal of Financial Economics, 8, 3-29. http://dx.doi.org/10.1016/0304-405X(80)90019-7 
DeAngelo, H., DeAngelo, L., \& Whited, T. (2011). Capital Structure Dynamics and Transitory Debt. Journal of Financial Economics, 99, 235-261. http://dx.doi.org/10.1016/j.jfineco.2010.09.005

Essein, U. A. (2009). Gender, informal credit markets and determinants of credit use by food crop farmers in Akwa Ibom State of Nigeria (M.Sc. Thesis). Michael Okpara University of Agriculture, Umudike, Nigeria.

Fama, E., \& French, K. (2002). Testing Trade-off and Pecking Order Predictions About Dividends and Debt. Review of Financial Studies, 15, 1-33. http://dx.doi.org/10.1093/rfs/15.1.1

Gaud, P., Jani, E., Hoesli, M., \& Bender, A. (2005). The Capital Structure of Swiss Companies: An Empirical Analysis Using Dynamic Panel Data. European Financial Management, 11(1), 51-69. http://dx.doi.org/10.1111/j.1354-7798.2005.00275.x

Higgins, R. C. (1977). How Much Growth Can a Firm Afford? Financial Management, 6(3), 7-16. http://dx.doi.org/10.2307/3665251

Huang, S. G. H., \& Song, F. M. (2002). The determinants of capital structure: evidences from China. working paper, School of Economics and Finance and Centre for China Financial Research.

Jensen, M. C., \& Meckling, W. (1976). Theory of The Firm: Managerial Behaviour, Agency Costs and Capital Structure. Journal of Financial Economics, 1976(3), 4.

Leary, M., \& Roberts, M. (2010). The Pecking Order, Debt Capacity, and Information Asymmetry. Journal of Financial Economics, 95, 332-355. http://dx.doi.org/10.1016/j.jfineco.2009.10.009

Liu, Y., Li, Y., Tao, L., \& Wang, Y. (2008). Relationship stability, trust and relational risk in marketing channels: Evidence from China. Ind. Market Management, 37(4), 432-446. http://dx.doi.org/10.1016/j.indmarman.2007.04.001

Mckinnon, R. I. (1973). Money and Capital in Economic Development. Washington, D.C.: Brookings Institutiion.

Morri, G., \& Beretta, C. (2008). The Capital Structure Determinants of REITs. Is it a Peculiar Industry? Journal of European Real Estate Research, 1(1), 6-57. http://dx.doi.org/10.1108/17539260810891488

Myers, S. C. (1984). The capital structure puzzle. Journal of Finance, 39, 575-592. http://dx.doi.org/10.2307/2327916

Myers, S. C. (2001). Capital structure. Journal of Economic Perspectives, 15, 81-102. http://dx.doi.org/10.1257/jep.15.2.81

Myers, S. C., \& Majluf, N. (1984). Corporate financing and investment decisions when firms have information that investors do not have. Journal of Financial Economics, 13, 187-221. http://dx.doi.org/10.1016/0304-405X(84)90023-0

Nwaru, J. C. (2004). Rural credit markets and resource use in arable crop production in Imo State of Nigeria. (Ph.D. Dissertation). Michael Okpara University of Agriculture, Umudike, Nigeria.

Pandey, M. (2004). Capital structure, profitability and market structure: evidence from Malaysia. Asia Pacific Journal of Economics and Business, 8(2).

Rajan, R. G., \& Zingales, L. (1995). What Do We Know About Capital Structure? Some Evidence from International Data. Journal of Finance, 50(5), $14 \quad \& \quad$ 21-60. http://dx.doi.org/10.1111/j.1540-6261.1995.tb05184.x

Roubini, N., \& Sal-i-Martin, X. (1992). Financial repression and Economic Growth. Journal of Development and economics, 39, 5-30. http://dx.doi.org/10.1016/0304-3878(92)90055-E

Schoubben, F., \& van Hulle, C. (2004). The determinants of leverage: differences between quoted and non quoted firms. Trijdschrift voor Economie en Management, XLIX(4), 589-620.

Schwartz, E., \& Aronson, J. (1967, March). Some Surrogate Evidence in Support of the Concept of Optimal Financial Structure. Journal of Finance, 22, 10-18.

Shyam-Sunder, L., \& Myers, S. C. (1999). Testing static tradeoff against pecking order models of capital structure. Journal of Financial Economics, 51, 219-244. http://dx.doi.org/10.1016/S0304-405X(98)00051-8

Uremadu, S. O. (2004). Financial Management: Concepts, Analysis and Applications. Enugu: Precision Publishers Limited.

Wang, C. L. (2007). Guanxi vs. relationship marketing: Exploring underlying differences. Ind. Market 
Management, 36(1), 81-86. http://dx.doi.org/10.1016/j.indmarman.2005.08.002

Westgaard, S., Eidet, A., Frydenberg, S., \& Grosas, T. C. (2008). Investigating the Capital Structure of UK Real Estate Companies. Journal of Property Research, 25(1), 61-87. http://dx.doi.org/10.1080/09599910802397107

Yang, H. (2000). The Real Estate Economics (2nd ed.). Dalian: Northeast Forestry University Press.

\section{Copyrights}

Copyright for this article is retained by the author(s), with first publication rights granted to the journal.

This is an open-access article distributed under the terms and conditions of the Creative Commons Attribution license (http://creativecommons.org/licenses/by/3.0/). 